\title{
The Effects of City Council Decisions on Financial Resources Management in Tehran Municipality
}

\author{
Faezeh Mirhashemi
}

\begin{abstract}
MA in Public Administration (Financial Major), Department of Management, Central Tehran branch
\end{abstract} Islamic Azad University, Tehran, Iran

\section{Hassan Almasi (Corresponding Author)}

PhD in Public Administration, Department of Management, Central Tehran branch Islamic Azad University, Tehran, Iran; Email: h_almasi@yahoo.com

Doi:10.5901/mjss.2015.v6n6s2p542

\section{Abstract}

The aim of the present study is to explore the effect of decisions made by city council on financial resources management in Tehran's municipality that for this purpose 200 of the managers, deputies and employees in the department of accounting and funds of Tehran's municipality have been selected with the use of simple random sampling method and have completed the research questionnaire. Content validity of this questionnaire has been confirmed by three of the experts and professors in this field and its reliability also has been confirmed with the use of Cronbach's alpha test. In the end, for analyzing the collected from research questionnaire and considering normality of data, two variable linear regression and Friedman's tests have been used. Obtained results from these tests indicates that decisions of city council and all its dimensions including technical, financial and civil decisions have a positive and significant effect $(p<0.01)$ on financial resources management of Tehran's municipality. Results also indicate that among the dimensions of city council's decision, dimension of civil decisions has the highest effect on financial resources management.

Keywords: city council decision, financial resources management, Tehran's municipality.

\section{Introduction}

Financial resources as a facilitator of financial flows, gives this opportunity to organizations to transfer their economic resources with reliance on monetary resources with a higher speed and accuracy. It is clear that this action will contribute to more efficient allocation of resources in case of having better competitive position and appropriate financial tools. Efficient allocation of resources is performed through Storage of financial instruments, in other words, these instruments allow consumer units to delay their expenses without reducing their nominal values to the desired time and period. In this way with storage of financial assets and predicting power of users of these resources, their allocations will be improved (Edwards, 2003).

\section{Review of Literature}

Various studies have been conducted with regards to the effect of different factors on volatility of liquidity in Stock Market of different countries (Amihud, 2002; Attig et al., 2006; Berkman et al., 1998; Kothare, 1997). In these studies the effect of stock return on liquidity (Amihud, 2002), effect of institutional investors to liquidity ratio (Attig et al., 2006), effect of short-term transactions on liquidity (Berkman et al., 1998) and effect of share issuance on liquidity (Kothare, 1997) have been conducted, however, a study that has conducted with the specific aim of exploring the effects of the decisions presented in board of directors on liquidity is the study of Himmelmann and Schiereck (2012). Maintaining good level of liquidity is one of the main duties in organizations and lack of attention to it would increase liquidity risk for that organization or institution (Amihud, 2002). On the other hand, success of so many organizations that are working as a Subsidiary of a holding or trust organizations directly or indirectly depends on the ability of the holding or trust organization in providing liquidity for its subsidiaries (Ginglinger and Hamon, 2007).

It should be noted that today opposing left and right traditional views and even new humanistic views are emphasizing on the importance of local government as An important part of management and governance of a society. 
This emphasis is due to a number of different reasons including: economic efficiency and local democracy for liberals, class power for low classes of a society for socialists and Marxists and finally protection of environment as well as protecting human life. It can be understood and summarized from different theories and movements with regards to the role of local governments is that with increases complexity of civil and urban society in the recent half a century, all the views have understood the importance of local governments as a governance and managerial instrument (Habibi and Saeedi Rezvani, 2005).

\section{Objective of the Study}

In the present study, researcher who is also an employee in Tehran's municipality, seeks to explore that to what extent the decisions of city council affects financial resources management in Tehran's municipality? Hence, in his study the effect of the decisions of city council on financial resources management in Tehran municipality will be studied.

\section{Research Model}

Due to this reason the variables of financial resources management in Tehran's municipality has been taken as dependent variable and the variables of decisions of the city council of Tehran with regards to Rial value of the approved projects and approved decisions of Tehran's city council with regards to Rial value of all the projects (including the approved and unapproved ones) has been taken as independent variable. In the following, research conceptual model will be first presented and after that research methodology, findings and conclusion will be presented.

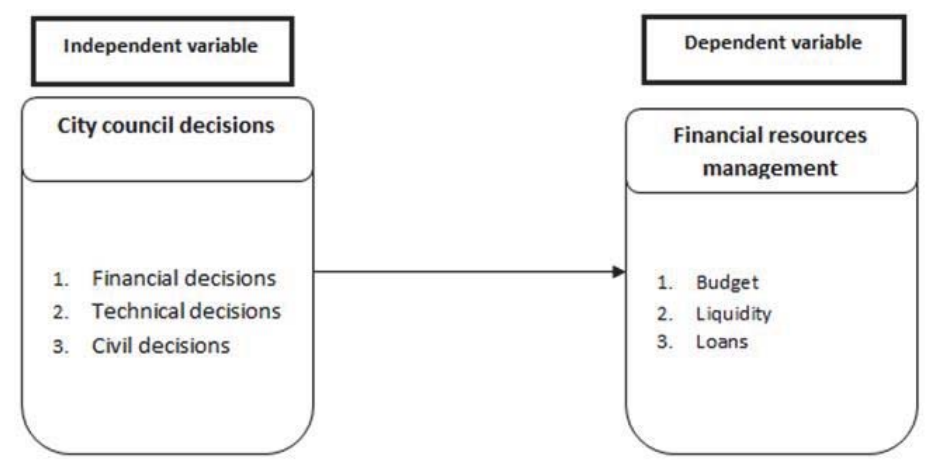

Figure 1: Research conceptual model adopted from Himmelmann \& Scheireck (2012) of administrative rules and procedures

\section{Research Methodology}

The present study is an applied research in terms of its goals and in terms of its method is a descriptive - correlation study.

\subsection{Population and sample}

Research population of the present study includes all the managers, deputies and employees working in accounting and budget department of Tehran's municipality that is equal to 419 people. Since, the statistical population in this study have a limited and specified number, therefore, for determining minimum required sample size, Cochran's formula for limited population has been used which has calculated to be equal to 200 people.

\subsection{Data collection instrument}

Data collection instruments are those tools and instruments that the researchers with the help of them can collect and 
obtain his required information and data. Different methods of data collection are questionnaire, observation and interview. In this study questionnaire has been used for collecting the responses of the target population. A questionnaire is a set of written questions that are developed with regards to variables in a study and are completed by respondents (participants) in person or from a distance, directly or indirectly. In this study, the questionnaire has been measured with the use of nominal and ordinal scales. Measurement scales are units that are used for measuring qualities and data collection instruments.

Content validity of the questionnaire has been confirmed by three of the experts and professors in this field and its reliability also has been tested with the use of Cronbach's alpha test which is equal to 0.89 for city council decisions questionnaire and 0.92 for financial resources management questionnaire.

\subsection{Research findings}

Results related to demographic characteristics of the present study indicate that $63.5 \%$ of individuals in the study sample are male and $36.5 \%$ are female and among them 1.5\% have less than 1 year of service, $14.5 \%$ have between 2 - 5 years of service, $22 \%$ have 6 to 10 years of service, 31\% have 11 - 15 years of service, $19.5 \%$ have 16 to 20 years of service and $11.5 \%$ also have 21 years of service and higher. In terms of the type of post also, $12 \%$ are managers, $24 \%$ are deputies, $46.5 \%$ are financial and budget experts and $17.5 \%$ are the members of city council.

Descriptive statistics related to research variables have been presented in table 1:

Table 1: Descriptive statistics of research variables

\begin{tabular}{lccc}
\hline Variable & Average & Mean & Standard deviation \\
\hline Financial decisions & 3.265 & 3.300 & 0.683 \\
Technical decisions & 2.913 & 3.000 & 0.766 \\
Civil decisions & 2.989 & 3.000 & 0.776 \\
City council decisions & 3.055 & 3.066 & 0.641 \\
Financial resources management & 3.132 & 3.125 & 0.682 \\
\hline
\end{tabular}

Results presented in table 1 indicate that among the dimensions of city council decisions, dimension of financial decisions with an average of 3.265 have the highest average and dimension of technical decisions with an average of 2.913 has the lowest average. The largest standard deviation is related to the dimension of civil decisions (0.776) and the lowest is related to dimension of financial decision (0.683). the two variables of city council decisions and financial resources management also respectively have an average of 3.055 and 3.132. Standard deviation of these variables is equal to 0.641 and 0.682 and their mean is equal to 3.066 and 3.125 , respectively.

For studying whether the effect of the dimensions of city council decisions and its dimensions on financial resources management in Tehran's municipality is significant two-variable linear regression test has been used, the results of which have been presented in table 2 .

Table 2: Results related to the extent to which dimensions of city council decisions affect financial resources management in Tehran municipality.

\begin{tabular}{lcccc}
\hline Variable & $\mathbf{R}^{\mathbf{2}}$ adj. & Beta & $\mathbf{F}$ & $\mathbf{P}$ \\
\hline Financial decisions & 0.20 & 0.452 & 50.751 & .00 \\
Technical decisions & 0.49 & 0.697 & 187.094 & .00 \\
Civil decisions & 0.82 & 0.906 & 910.665 & .00 \\
City council decisions & 0.65 & 0.804 & 360.878 & .00 \\
\hline
\end{tabular}

Results of two-variable linear regression test indicate that city council's decisions and its dimensions including financial, technical and civil decisions has a significant effect $(p<0.01)$ on financial resources management in Tehran's municipality. For ranking the effective dimensions on financial resources management in Tehran's municipality Friedman's test has been used that its results have been presented below in table 3 . 
Table 3: Results of Friedman's ranking test

\begin{tabular}{lcc}
\hline Variable & Rank average & Rank \\
\hline Financial decisions & 1.73 & 3 \\
Technical decisions & 1.92 & 2 \\
Civil decisions & 2.35 & 1 \\
Sig. level: $p<0.001$ & Chi-square test: 45.501 & \\
\hline
\end{tabular}

Considering the results presented in table 3 and considering the significance level smaller than 0.001 , there is a significant difference between the dimensions of city council's decisions in terms of their effect on financial resources management in Tehran's municipality. In a way that civil decisions has the 1st rank, technical decisions has the 2nd rank and financial decisions has the 3rd rank.

\section{Conclusion}

Today budget is not only the forecast of expenses and incomes, but is a comprehensive administrative, economic and social plan. In a way that one of the most important concern of any government in economy area is regulation of financial relations, maintaining monetary value, accurate registration of earnings and calculating country's expenditures. One of the negligence of government and parliament as well as regulatory bodies is negligence with regards to Failure to accurately forecast revenues and being undisciplined in costs and expenditures (Pirnia, 1991).

Due to the importance of public budget in public organizations as well as in private companies and banks, the issue of preparation and proposing budget plan and implementing it and aligning the financial and administrative systems with this budget have been started recently and have become common. Initiation of this practice and its importance started when as the result of efforts and struggles throughout the world, first in England and later on in other countries, the right to impose tax and approval of public expenditure was assigned to people selected by public and people. Emergence of constitutional government and significant rules and regulations existing in such a government for a public entity in the country's Income and expenditure caused the budget issue to become rapidly popular.

By budget the goals of administrative bodies regarding the government budget and the goals of operating entities in companies and agencies are evaluated and their relative values is determined. All financial entities including governmental and non-governmental have limited income at their disposal and for spending this income they have multiple and various goals and objectives. Regarding the government its multiple goals are defending and maintaining national security, implementation of economic development justice, creating ways and instruments of communication, public culture, public health and so on. Therefore, the most important and fundamental step in the government and for administrative entity of the country is that this limited income should be divided for various and multiple needs and requirements in a way that by this division maximum benefit can be extracted from this income for the goals and objectives of the government. It means that a budget plan should be prepared, because as it was mentioned earlier also budget refers to a financial plan that defines the way public funds are being divided for the different needs and goals of the country (Pirnia, 1991).

From the perspective of income and for facing unstable financial capacities, municipality is facing major constraints. At the same time, current mechanisms for earn income and revenue in some fields such as sales of building density has caused unpleasant external outcomes such as reduced trust and Breach of privacies (Salehi Amiri and Sepideh, 2010).

Hence, municipality is a non-governmental public entity that with relying on incomes obtained from duties paid by citizens and other legal incomes is responsible to provide public services and products in the city area that considering the incomes this organization have from the following places it provides various services to citizens: 1- duties from urban development, 2- duties from renovation, 3 - construction and sales of building density, 4 - construction permits and so on (Salehi Amiri and Sepide, 2010).

Considering the fact that the plan of creating welfare facilities by Tehran's municipality for people has been determined as one of the priorities in 5th development plan and considering high sensitivity of Tehran regarding the quality of contractual projects in terms of time of delivery and liquidity available to Tehran's municipality and the mutual relationship between these two variables, importance of conducting studies in this field, especially regarding the liquidity level in Tehran's municipality that provides support to both the variables of reducing time widow of implementing projects and increasing quality of these projects is felt. Also, the mutual relationship between city council decisions and the decisions made by managers in Tehran's municipality has increased the importance of conducting such as study 
significantly. Hence, considering the fact that so far no study has been conducted specifically to explore the effect of city council's decisions on liquidity effects in Tehran's municipality in our country, the present study has been conducted with the aim of exploring the effect of city council's decision on financial resources management in Tehran's municipality and the results obtained from this study indicate that the effect of decisions made by city council and its dimensions including financial, technical and civil decisions are significant $(p<0.01)$ on financial resources management in Tehran's municipality.

The rules and regulations of municipalities in the form of Islamic council decisions in every city become legalized. These rules and regulations are announced by city councils to municipalities. Mayor in other words, is the head of the executive entity of the city, that is, should implement everything that is approved by city council members. The mayor has the responsibility to implement the approved rules and regulations that this will affect the financial resources management in municipality.

\section{References}

Amihud, Y. (2002). Exchange rates and the valuation of equity shares, published in Y. Amihud and R. M. Levich [eds.], Exchange rates and corporate performance, Irwin, New York, pp. 49-59.

Attig, N., Gadhoum, Y., \& Lang,L. (2003). Bid-Ask Spread, Asymmetric Information and Ultimate Ownership. EFMA Helsinki. Available at SSRN: http://ssrn.com/abstract=332020

Berkman, H., Bradbury, M.E., \& Magan, S. (1998). An international comparison of derivatives use, Financial Management, 26, 69-73.

Habibi, M., \& Saeedi Rezwani, H. (2005). Participatory Urban Development; a theoretical exploration in the context of Iran. Tehran, Fine Art Magazine, issue 24.

Kothare, M. (1997). The effects of equity issues on ownership structure and stock liquidity: A comparison of rights and public offerings, Journal of Financial Economics 43 (1), 131-148.

Pirnia, H. (1991). Public finance of taxes and budget. Tehran: Ibn Sina Publications.

Salehi Amiri, S.R., \& Sepideh, M. (2010). To explore and determine damage factors in relationship between Islamic city council and municipality (case study: Islamic city council and Tehran's municipality). Urban Management Studies, 2 (2), 22-32. 